doc. dr. sc. Mirjana Hladika

Ekonomski fakultet, Sveučilište u Zagrebu Zagreb, Republika Hrvatska mhladika@efzg.hr

Ivana Valenta, mag. oec.

Ekonomski fakultet, Sveučilište u Zagrebu, Zagreb, Republika Hrvatska ivalenta@efzg.hr

Ivica Milčić, univ. spec. oec.

Hrvatska zajednica računovođa i financijskih djelatnika, Zagreb, Republika Hrvatska imilcic@rif.hr

\title{
ANALIZA MEĐUOVISNOSTI IZMEĐU NOVČANOG TOKA I ZADUŽENOSTI U HOTELSKOJ INDUSTRIJI U REPUBLICI HRVATSKOJ
}

Primljen: 1. rujna 2018.

Prihvaćen: 30. studenog 2018.

Pregledni rad

\section{Sažetak}

Poduzeća u suvremenom poslovnom okruženju izložena su jakoj konkurenciji, stalno su u određenoj vrsti natjecanja, stoga u cilju preživljavanja i opstanka moraju proširivati i unaprjeđivati svoje aktivnosti, usluge i proizvode temeljem kojih generiraju rast i profitabilnost. Rast se treba financirati, a ključno je pitanje kako novčani tokovi i dugovi utječu jedni na druge. Cilj poslovanja svih poduzeća je osiguravanje dostatnih novčanih sredstava za podmirivanje obveza (dugova) poduzeća prema dobavljačima, zaposlenicima, kreditorima i ostalim vjerovnicima, ali i za nova ulaganja. Ako poduzeće ne podmiruje svoje dospjele obveze, ono se može suočiti s nelikvidnošću i problemima sa solventnosti. Poduzeće ne bi trebalo zadržavati značajna novčana sredstva već bi ista trebalo usmjeravati u aktivnosti s ciljem povećanja profitabilnosti, stoga bi poduzeća svoju politiku upravljanja novčanim sredstvima trebala temeljiti na zadovoljavanju odnosno servisiranju dugova prema eksternim izvorima financiranja, dok bi određeni iznos novčanih sredstava trebao biti investiran u projekte i aktivnosti koji bi generirali buduće novčane tokove i čime bi se poboljšala profitabilnost poduzeća. Cilj ovog rada je analizirati međuovisnost između novčanog toka od poslovnih aktivnosti i zaduženosti poduzeća iz hotelske industrije, te utvrđivanje novčanog pokrića ukupnih obveza za poduzeća iz hotelske industrije u Republici Hrvatskoj.

Ključne riječi: novčani tok, zaduženost, hotelska industrija, Hrvatska

JEL: M40, M41 


\section{UVOD}

Za menadžere svakog poduzeća odnosno svake organizacijske jedinice ostvareni novčani tokovi važan su pokazatelj i dio su njihove odgovornosti. S druge strane, investitori, kreditori, zaposlenici, potrošači (klijenti) zainteresirani su za informacije o novcu. Sposobnost poduzeća da generira novčane tokove postaje sve poželjnija i važnija kako bi se osigurali resursi koji su potrebni poduzeću, ali i kako bi se isplatile dividende vlasnicima, a bonusi menadžerima.

Menadžerske odluke u velikoj su mjeri povezane i ovise o novčanim tokovima. Novac je jedan od vitalnih i važnih resursa u svakom poduzeću, a generiranje i predviđanje budućih novčanih tokova najvažniji je preduvjet učinkovitog upravljanja.

Za donošenje kvalitetnih poslovnih odluka, uključujući financijske i investicijske odluke, nedostatak informacija o novčanim tokovima može biti ograničavajuće za interne i eksterne donositelje odluka. Određeni financijski pokazatelji mogu pomoći dionicima u procjeni strukture izvora financiranja poduzeća. Stoga je važno utvrditi kakav je učinak duga (dugova) na novčane tokove poduzeća (Gurtani i Mehr, 2015, 57). U tom kontekstu, cilj ovog rada je analizirati međuovisnost između novčanog toka od poslovnih aktivnosti i zaduženosti poduzeća iz hotelske industrije, te utvrđivanje novčanog pokrića ukupnih obveza za poduzeća iz hotelske industrije u Republici Hrvatskoj.

\section{ZNAČAJ I KORISNOST INFORMACIJA O NOVČANIM TOKOVIMA}

Izvještaj o novčanim tokovima je financijski izvještaj koji je proizašao iz potrebe menadžmenta za dodatnim informacijama za svrhu donošenja poslovnih odluka. Na globalnoj razini danas je korist od izvještaja o novčanim tokovima velika, pa čak tolika da sve više zasjenjuje informacije koje su prezentirane u bilanci i računu dobiti i gubitka (Gulin, Hladika, 2018, 104).

Izvještaj o novčanim tokovima korisnicima pruža informacije o načinu na koji poduzeće stvara novac i kako troši novac. Informacije koje su prezentirane u izvještaju o novčanim tokovima korisnicima financijskih izvještaja predstavljaju temelj za ocjenu sposobnosti poduzeća da stvori novac i novčane ekvivalente, te za ocjenu potrebe poduzeća za novcem i novčanim ekvivalentima. Vanjski i unutarnji korisnici financijskih izvještaja zainteresirani su za informacije iz čega i u kojem iznosu pojedino poduzeće ostvaruje novčane primitke, te zbog čega nastaju i koliki su novčani izdaci iz pojedinih aktivnosti (Gulin, Hladika, 2018, 104).

Temeljem navedenog, izvještaj o novčanim tokovima treba pomoći investitorima i kreditorima za ocjenu (Gulin, Perčević, 2013, 39): 
a) sposobnosti poduzeća da ostvari budući pozitivni čisti novčani tok

b) sposobnosti poduzeća da podmiri obveze vjerovnicima i isplati dividende te da se ocijene potrebe poduzeća za vanjskim financiranjem

c) razloga zbog kojih se neto dobit poduzeća razlikuje od čistog novčanog toka i

d) da se omogući procjena učinaka novčanog toka te raznih nenovčanih investicijskih $\mathrm{i}$ financijskih aktivnosti tijekom razdoblja na financijski položaj poduzeća.

Izvještaj o novčanim tokovima mora prikazivati novčane tokove (novčane primitke i novčane izdatke) nastale tijekom razdoblja razvrstane na novčane tokove od poslovnih, investicijskih i financijskih aktivnosti. Razvrstavanje novčanih tokova po pojedinim aktivnostima korisnicima pruža informacije koje im omogućavaju procjenu utjecaja pojedine aktivnosti na financijski položaj poduzeća i iznos njegova novca i novčanih ekvivalenata. Najvažnija i najkorisnija informacija u izvještaju o novčanim tokovima je informacija o novčanom toku iz poslovnih aktivnosti.

Korisnici financijskih izvještaja koriste financijske izvještaje pojedinih poduzeća kako bi ocijenili njihovu likvidnost, zaduženost, aktivnost imovine, profitabilnost i uspješnost poslovanja. Dugi niz godina korisnici financijskih izvještaja ocjenjivali su financijsku uspješnost na temelju bilance i računa dobiti i gubitka kao financijskih izvještaja temeljenih na obračunskoj osnovi. Budući da se dobit utvrđuje kao razlika prihoda i rashoda, odnosno na temelju obračunskih kategorija, mnogi su kritizirali validnost te mjere uspješnosti te su naglašavali da novac i novčani tokovi (financijske kategorije) predstavljaju činjenicu i mjere stvarnu uspješnost poslovanja poduzeća. Pri tome je naglasak dan na novčane tokove iz poslovnih aktivnosti budući da poslovne aktivnosti predstavljaju aktivnosti iz kojih poduzeće generira glavne prihode, a poduzeće je uspješnije što se veći dio tih prihoda stvarno i naplati. U tom kontekstu, izraz „,Novac je kralj “ (,, Cash is King “) danas je široko shvaćen i poštovan među različitim stakeholderima.

Zeller i Stanko (1994), Mills i Yamamura (1998) i Mossman, Bell, Swartz i Turtle (1998) u svojim istraživanjima su naglašavali značajnost informacija o novčanim tokovima za različite korisnike financijskih izvještaja. Korisnici financijskih izvještaja (investitori, kreditori i ostali) zahtijevaju informacije o vremenu i iznosu novčanih tokova za potrebe donošenja poslovnih odluka. Uspješno poduzeće bi trebalo poslovati s dobiti te bi trebalo generirati novac, a najznačajniji je novčani tok od poslovnih aktivnosti (Bhandari, Iyer, 2013, 669).

Važnost novca ogleda se u činjenici da se njime, a ne ostvarenom dobiti, kupuje imovina (strojevi, zgrade, prijevozna sredstva, dionice i ostalo), isplaćuju plaće, plaćaju usluge i ostale obveze prema dobavljačima, podmiruju obveze prema kreditorima, plaćaju porezi i ostalo. Zbog toga se poduzeća s nedostatnim novcem 
mogu dovesti do situacije u kojoj više nisu u mogućnosti pravovremeno ispunjavati svoje dospjele obveze što u konačnici vodi prema stečaju.

Uvođenjem izvještaja o novčanim tokovima kao integralnog dijela cjelovitog seta financijskih izvještaja korisnicima financijskih izvještaja na raspolaganju su nove informacije za financijsku procjenu poduzeća odnosno za procjenu financijske uspješnosti poduzeća (Jooste, 2006, 569). Poslovne odluke mogu biti različite ovisno o tome koriste li korisnici financijskih izvještaja informacije iz bilance i računa dobiti i gubitka koje su temeljene na obračunskoj osnovi ili se koriste informacije iz izvještaja o novčanim tokovima koji se temelji na novčanoj osnovi (Gulin, Hladika, 2017).

Brojni su se autori složili da su informacije o novčanom toku (novčanim tokovima) bolji indikator financijske uspješnosti u odnosu na tradicionalne zarade (dobit) (Lee, 1982; Giacomo i Mielke, 1993). Jooste $(2006,571)$ ističe da je u vrijeme povećanih troškova, povećanih ulaganja u radni kapital i visokih troškova zamjene fiksne imovine potrebno značajniju pozornost usmjeriti na novčane tokove.

Fabozzi i Drake $(2010,288)$ naglašavaju da se na temelju analize novčanih tokova poduzeća mogu dobiti informacije o ključnim izvorima financiranja poslovanja poduzeća, informacije o ovisnosti poduzeća o eksternim izvorima financiranja (zaduživanju), kao i informacije o kvaliteti ostvarenih zarada (na temelju razlike između ostvarene dobiti i novčanih tokova). Gulin $(2016,30)$ ističe da je korisnicima financijskih izvještaja povećana usporedivost izvještaja različitih poduzeća budući da informacije koje su prezentirane u izvještaju o novčanim tokovima eliminiraju učinke različitih računovodstvenih postupaka prilikom evidentiranja istih poslovnih događaja.

Pokazatelji na temelju izvještaja o novčanom toku korišteni zajedno s tradicionalnim pokazateljima na temelju bilance i računa dobiti i gubitka trebali bi dovesti do boljeg razumijevanja financijske snage i slabosti poduzeća.

\section{PREGLED PRETHODNIH ISTRAŽIVANJA}

Brojni su autori proveli istraživanja o analizi odnosa između pokazatelja uspješnosti i zaduženosti poduzeća. Pri tome su neki autori kao mjeru uspješnosti poslovanja uzimali tradicionalni pokazatelj odnosno dobit, dok su drugi autori novčani tok smatrali prikladnijom i pouzdanijom mjerom uspješnosti poslovanja poduzeća, i to novčani tok od poslovnih aktivnosti.

Matemilola, Bany-Ariffin i Nassir Annuar (2014) u svom su istraživanju na uzorku poduzeća iz Južne Afrike (2004-2009) utvrdili da je novčani tok negativno povezan s pokazateljem dugoročne zaduženosti i pokazateljima ukupne 
zaduženosti. Iz njihova se istraživanja generiraju zaključci da postoji potreba za daljnjim razvojem tržišta kapitala kako bi se minimizirao problem asimetrije informacija između poduzeća i njihovih financijera, te kako bi se poduzećima omogućio lakši pristup financiranju dugom (iz eksternih izvora) i vlastitim izvorima (kapitalom). Također, rezultati njihova istraživanja su pokazali da poduzeća s većim novčanim tokom imaju manji iznos duga u strukturi pasive bilance odnosa u strukturi izvora financiranja poduzeća. Rezaei i Jafari (2015) proveli su istraživanje na uzorku poduzeća koja kotiraju na Teheranskoj burzi, te su rezultati tog istraživanja pokazali postojanje značajnog negativnog odnosa između novčanog toka i pokazatelja zaduženosti. Fama i French (2002) su u svom empirijskom istraživanju dokazali da je interno financiranje (dobit ili novčani tok) negativno povezano s dugom poduzeća. Allen (1993) je u svom istraživanju pokazao da dobit ima negativne učinke na dugove poduzeća, a istraživanje je provedeno na uzorku australskih poduzeća. Baskin (1989) je u svom istraživanju utvrdio postojanje negativnog odnosa između dobiti i dugova poduzeća. Tong i Green (2005) su dokazali postojanje negativnog odnosa između dobiti i zaduženosti poduzeća na uzorku kineskih poduzeća. Sen i Eda (2008) u svom istraživanju su potvrdili postojanje negativnog odnosa između dobiti i pokazatelja zaduženosti.

\section{METODOLOGIJA I REZULTATI ISTRAŽIVANJA}

\subsection{Metodologija istraživanja}

Cilj ovog rada je analiza novčanog toka od poslovnih aktivnosti i ukupnih obveza te utvrđivanje novčanog pokrića ukupnih obveza za hotelsku industriju. Prilikom analize korišteni su javno dostupni podaci preuzeti iz Registra godišnjih financijskih izvještaja za hotelsku industriju u razdoblju od 2010. do 2015. godine. Za 2015. godinu u Republici Hrvatskoj godišnje financijske izvještaje su predala 84 velika i srednja hotela. Od ukupnog broja hotela, za 50 hotela (poduzeća) je bilo moguće prikupiti potpune podatke kroz cijelo promatrano razdoblje.

\subsection{Rezultati istraživanja}

Metodama deskriptivne statistike je analiziran novčani tok od poslovnih aktivnosti. U tablici 1. vidljiv je postotak poduzeća koja su u promatranom razdoblju ostvarila pozitivan novčani tok od poslovnih aktivnosti. 
Tablica 1. Postotak poduzeća koja su ostvarila pozitivan novčani tok od poslovnih aktivnosti 2010. 2011. 2012. 2013.2014 .2015$.

\begin{tabular}{|l|l|l|l|l|l|l|}
\hline Pozitivan novčani tok & $74 \%$ & $82 \%$ & $80 \%$ & $90 \%$ & $82 \%$ & $94 \%$ \\
\hline Negativan novčani tok & $26 \%$ & $18 \%$ & $20 \%$ & $10 \%$ & $18 \%$ & $6 \%$ \\
\hline
\end{tabular}

Izvor: Obrada autora

Vidljiv je značajan trend povećanja broja poduzeća koja ostvaruju pozitivan novčani tok iz poslovnih aktivnosti. U 2015. godini je 94\% ukupno promatranih poduzeća ostvarivalo pozitivan novčani tok. Negativan novčani tok je najviše promatranih hotela ostvarilo tijekom 2010. godine u čemu je vidljiv utjecaj recesije u Republici Hrvatskoj i svijetu na poslovanje hotela. Kroz promatrano razdoblje vidljivo je kako se broj poduzeća $\mathrm{s}$ negativnim novčanim tokom iz poslovnih aktivnosti znatno smanjio što može upućivati na oporavak hotelske industrije i na poboljšanje uspješnosti poslovanja poduzeća iz hotelske industrije. Kako bi se mogli donijeti validni zaključci vezano uz pozitivan novčani tok, potrebno je analizirati novčani tok iz poslovnih aktivnosti kroz razdoblja.

U tablici 2. nalaze se ukupni podaci o pozitivnom novčanom toku iz poslovnih aktivnosti poduzeća iz hotelske industrije kroz promatrano razdoblje.

Tablica 2. Analiza pozitivnog novčanog toka od poslovnih aktivnosti

\begin{tabular}{|c|c|c|c|c|c|c|}
\hline & 2010. & 2011. & 2012 & 2013. & 2014. & 2015. \\
\hline $\begin{array}{c}\text { Aritmetička } \\
\text { sredina }\end{array}$ & 23.451 .102 & 27.037 .969 & 33.421 .053 & 31.514 .850 & 47.052 .816 & 40.710 .956 \\
\hline $\begin{array}{c}\text { Standardna } \\
\text { pogreška }\end{array}$ & 5.460 .901 & 6.487 .756 & 8.323 .011 & 7.534 .422 & 11.569 .293 & 10.131 .082 \\
\hline Medijan & 12.480 .441 & 9.773 .992 & 14.899 .432 & 12.930 .211 & 22.281 .926 & 17.869 .282 \\
\hline $\begin{array}{c}\text { Standardna } \\
\text { devijacija }\end{array}$ & 33.217 .365 & 41.541 .905 & 51.977 .184 & 50.542 .436 & 74.079 .620 & 69.455 .199 \\
\hline Kurtosis & 7 & 6 & 6 & 11 & 6 & 11 \\
\hline Asimetrija & 3 & 3 & 3 & 3 & 3 & 3 \\
\hline Raspon & 146.844 .129 & 177.831 .779 & 204.038 .222 & 249.326 .284 & 326.934 .486 & 356.231 .103 \\
\hline Minimum & 153.547 & 620.773 & 1.325 .450 & 2.200 & 13.770 & 455.003 \\
\hline Maksimum & 146.997 .676 & 178.452 .552 & 205.363 .672 & 249.328 .484 & 326.948 .256 & 356.686 .106 \\
\hline Zbroj & 867.690 .763 & 1.108 .556 .745 & 1.303 .421 .051 & 1.418 .168 .236 & 1.929 .165 .469 & 1.913 .414 .935 \\
\hline Broj & 37 & 41 & 39 & 45 & 41 & 47 \\
\hline
\end{tabular}

Izvor: Obrada autora 
Analizirajući dobivene podatke, vidljivo je da dolazi do naglog povećanja prosječnog pozitivnog novčanog toka u 2014. i 2015. godini. Međutim, aritmetička sredina u ovoj analizi nije prikladan pokazatelj zbog velike standardne devijacije, zatim zbog koeficijenta asimetrije koji pokazuje pozitivnu asimetričnost što znači da distribucija nije normalno distribuirana te ukazuje da u podacima postoje izdvojenice koje zaista u ovoj analizi značajno utječu na rezultate. Kao prikladnija mjera središnje tendencije uzima se medijan koji pokazuje kako je 2010. godine $50 \%$ i manje poduzeća ostvarivalo pozitivan novčani tok od $12.480 .411 \mathrm{kn}$ ili manje, dok je ostalih $50 \%$ ostvarilo pozitivan novčani tok od poslovnih aktivnosti veći od $12.480 .411 \mathrm{kn}$. U 2015. godini 50\% i manje poduzeća je ostvarivalo novčani tok od poslovnih aktivnosti od 17.869.282 kn i manje, a ostalih 50\% poduzeća je ostvarivalo novčani tok od poslovnih aktivnosti veći od tog iznosa. Navedeno dovodi do zaključka kako je kroz promatrano razdoblje došlo do povećanja novčanog toka od poslovnih aktivnosti.

Za izračun novčanog pokrića obveza poduzeća potreban je podatak o ukupnim obvezama poduzeća kroz promatrano razdoblje, stoga se u radu analiziraju ukupne obveze kako bi se analizirao trend i donijeli zaključci o kretanju ukupnih obveza.

U Tablici 3. prikazana je deskriptivna analiza ukupnih obveza poduzeća iz hotelske industrije u razdoblju od 2010. do 2015. godine.

Tablica 3. Analiza ukupnih obveza

\begin{tabular}{|c|c|c|c|c|c|c|}
\hline & $\mathbf{2 0 1 0 .}$ & $\mathbf{2 0 1 1 .}$ & $\mathbf{2 0 1 2 .}$ & $\mathbf{2 0 1 3 .}$ & $\mathbf{2 0 1 4 .}$ & $\mathbf{2 0 1 5 .}$ \\
\hline $\begin{array}{c}\text { Aritmetička } \\
\text { sredina }\end{array}$ & 200.712 .632 & 210.581 .512 & 214.963 .674 & 221.288 .968 & 236.119 .365 & 243.722 .586 \\
\hline $\begin{array}{c}\text { Standardna } \\
\text { pogreška }\end{array}$ & 38.679 .238 & 42.640 .278 & 43.099 .319 & 44.999 .191 & 47.971 .423 & 49.119 .203 \\
\hline Medijan & 109.288 .533 & 118.873 .300 & 121.817 .266 & 111.070 .862 & 116.995 .065 & 113.468 .585 \\
\hline $\begin{array}{c}\text { Standardna } \\
\text { devijacija }\end{array}$ & 273.503 .517 & 301.512 .300 & 304.758 .208 & 318.192 .330 & 339.209 .185 & 347.325 .217 \\
\hline Kurtosis & 7 & 8 & 9 & 8 & 8 & 8 \\
\hline Asimetrija & 3 & 3 & 3 & 3 & 3 & 3 \\
\hline Raspon & 1.281 .008 .069 & 1.461 .252 .219 & 1.555 .452 .185 & 1.616 .127 .156 & 1.738 .210 .638 & 1.705 .234 .613 \\
\hline Minimum & 3.916 .590 & 3.321 .090 & 3.978 .708 & 4.530 .989 & 4.063 .684 & 4.593 .589 \\
\hline Maksimum & 1.284 .924 .659 & 1.464 .573 .309 & 1.559 .430 .893 & 1.620 .658 .145 & 1.742 .274 .322 & 1.709 .828 .202 \\
\hline Zbroj & 10.035 .631 .575 & 10.529 .075 .575 & 10.748 .183 .688 & 11.064 .448 .389 & 11.805 .968 .238 & 12.186 .129 .284 \\
\hline Broj & 50 & 50 & 50 & 50 & 50 & 50 \\
\hline
\end{tabular}

Izvor: Obrada autora

Analizom ukupnih obveza svih hotelskih poduzeća u uzorku kao i u prethodnoj analizi moguće je vidjeti kako aritmetička sredina nije prikladan pokazatelj središnje vrijednosti, stoga se kao prikladnija mjera uzima medijan. Medijan prikazuje kako je 50\% i manje poduzeća imalo ukupne obveze u 2015. godini u iznosu 
od 113 milijuna kuna ili manje, dok je 50\% i više poduzeća imalo ukupne obveze veće od 113 milijuna kuna. Ukoliko se analizira zbroj ukupnih obveza svih poduzeća u promatranom razdoblju vidljivo je kako se isti konstantno povećavao. Iz navedenog se može zaključiti da je do povećanja došlo zbog novih investicija u hotelske kapacitete koji su većinom financirani iz dugoročnih izvora financiranja, i to kreditima banaka.

Nakon analize pozitivnog novčanog toka iz poslovnih aktivnosti i ukupnih obveza, može se izračunati pokazatelj novčanog pokrića ukupnih obveza. Analiza je napravljena na način da je za svako poduzeće u svakoj godini u promatranom razdoblju izračunat pokazatelj, a zatim su zbirno analizirani podaci za poduzeća koja su ostvarila pozitivan novčani tok od poslovnih aktivnosti te je utvrđena prosječna vrijednost i ostali pokazatelji središnje vrijednosti i mjere raspršenosti. U tablici 4. prikazana je deskriptivna analiza pokazatelja novčanog pokrića ukupnih obveza za poduzeća iz hotelske industrije u razdoblju od 2010. do 2015. godine.

Tablica 4. Analiza pokazatelja novčanog pokrića ukupnih obveza

\begin{tabular}{|c|c|c|c|c|c|c|}
\hline & $\mathbf{2 0 1 0 .}$ & $\mathbf{2 0 1 1}$ & $\mathbf{2 0 1 2}$ & $\mathbf{2 0 1 3 .}$ & $\mathbf{2 0 1 4 .}$ & $\mathbf{2 0 1 5 .}$ \\
\hline Aritmetička sredina & 0,496677 & 0,548303 & 0,547894 & 0,475913993 & 0,55091 & 0,296321 \\
\hline Standardna pogreška & 0,184416 & 0,200281 & 0,167133 & 0,149589392 & 0,17942 & 0,083824 \\
\hline Medijan & 0,123134 & 0,138316 & 0,165556 & 0,16157338 & 0,167058 & 0,182919 \\
\hline Standardna devijacija & 1,121761 & 1,282423 & 1,043744 & 1,003476145 & 1,148847 & 0,574668 \\
\hline Varijacija uzorka & 1,258348 & 1,64461 & 1,089402 & 1,006964373 & 1,319848 & 0,330244 \\
\hline Kurtosis & 10,27376 & 13,32017 & 6,707632 & 6,970061554 & 12,14861 & 32,75751 \\
\hline Asimetrija & 3,246009 & 3,587706 & 2,775603 & 2,866953735 & 3,459504 & 5,387604 \\
\hline Raspon & 5,200927 & 6,535074 & 4,020432 & 4,031285096 & 5,748588 & 3,83747 \\
\hline Minimum & 0,001069 & 0,00397 & 0,005106 & $9,0489 \mathrm{E}-05$ & 0,000115 & 0,002276 \\
\hline Maksimum & 5,201996 & 6,539044 & 4,025538 & 4,031375585 & 5,748702 & 3,839746 \\
\hline Zbroj & 18,37704 & 22,48043 & 21,36788 & 21,41612967 & 22,58731 & 13,92708 \\
\hline Broj & 37 & 41 & 39 & 45 & 41 & 47 \\
\hline
\end{tabular}

Izvor: Obrada autora

Pokazatelj novčanog pokrića ukupnih obveza pokazuje koliko je poduzeću potrebno da iz novčanog toka podmiri sve svoje obveze. Svakom poduzeću je cilj da to vrijeme bude što kraće kako bi poslovanje poduzeća bilo što stabilnije. Pokazatelj novčanog pokrića ukupnih obveza treba biti što veći, odnosno broj godina otplate ukupnih obveza iz novčanog toka od poslovnih aktivnosti bi trebao biti što manji. Prilikom analize svih podataka vidljivo je da distribucija nije normalno distribuirana nego je pozitivno asimetrična što upućuje na ekstremne pozitivne vrijednosti, stoga aritmetička sredina treba biti zanemarena i veća važnost treba biti na pokazateljima na koje ekstremne vrijednosti nemaju toliki utjecaj, poput medijana. Ekstremne vrijednosti u analizi pokazatelja novčanog pokrića ukupnih 
obveza prikazuju da u hotelskoj industriji postoje hoteli (poduzeća) koji su jako malo zaduženi a ostvaruju značajne pozitivne novčane tokove od poslovne aktivnosti. Također, u analizi je utvrđeno da su uzorkom obuhvaćeni hoteli čije su dugoročne obveze vrlo visoke a novčani tok iz poslovnih aktivnosti izrazito nizak što zasigurno dovodi u pitanje opstanak poslovanja tih hotela. Za lakšu interpretaciju navedenog pokazatelja potrebno je rezultate analizirati na način da se utvrdi koliko je godina potrebno poduzećima da iz novčanog toka od poslovnih aktivnosti, koji je glavni generator novca u poduzeću, pokrije sve svoje obveze.

Tablica 5. Broj godina potrebnih za otplatu ukupnih obveza

\begin{tabular}{|c|c|c|c|c|c|c|}
\hline & $\mathbf{2 0 1 0}$ & $\mathbf{2 0 1 1}$ & $\mathbf{2 0 1 2}$ & $\mathbf{2 0 1 3}$ & $\mathbf{2 0 1 4}$ & $\mathbf{2 0 1 5}$ \\
\hline Aritmetička sredina & 44,61 & 19,84 & 19,73 & 30,13 & 10,70 & 29,28 \\
\hline Standardna pogreška & 25,94 & 6,38 & 5,98 & 10,00 & 3,00 & 12,10 \\
\hline Medijan & 8,12 & 7,23 & 6,04 & 6,16 & 5,81 & 5,47 \\
\hline Standardna devijacija & 157,81 & 40,88 & 37,36 & 65,55 & 18,95 & 82,93 \\
\hline Varijacija uzorka & 24902,87 & 1670,89 & 1395,87 & 4296,81 & 358,92 & 6876,71 \\
\hline Kurtosis & 30,25 & 27,05 & 12,89 & 11,57 & 22,33 & 19,66 \\
\hline Asimetrija & 5,38 & 4,85 & 3,32 & 3,33 & 4,41 & 4,47 \\
\hline Raspon & 935,28 & 251,76 & 195,58 & 331,61 & 112,45 & 439,02 \\
\hline Minimum & 0,19 & 0,15 & 0,25 & 0,25 & 0,17 & 0,26 \\
\hline Maksimum & 935,47 & 251,91 & 195,83 & 331,86 & 112,62 & 439,28 \\
\hline Zbroj & 1650,74 & 813,36 & 769,54 & 1295,41 & 427,91 & 1376,22 \\
\hline Broj & 37 & 41 & 39 & 43 & 40 & 47 \\
\hline
\end{tabular}

Izvor: Obrada autora

U tablici 5. se nalazi analiza broja godina potrebnih za podmirenje ukupnih obveza poduzeća iz novčanog toka od poslovnih aktivnosti kroz promatrano razdoblje. Medijan u 2010. godini pokazuje kako je za 50\% poduzeća i manje potrebno 8 godina za podmirenje ukupnih obveza, dok je za 50\% i više poduzeća potrebno više od 8 godina. Od 2010. godine vidljiv je trend smanjenja vrijednosti medijana i u 2015. godini on iznosi 5,5 godina. Iako je u prethodnim analizama utvrđeno kako je u promatranom razdoblju došlo do povećanja novčanog toka od poslovnih aktivnosti i ukupnih obveza, može se zaključiti kako je porast novčanog toka od poslovnih aktivnosti bio brži i veći. Navedeno se može objasniti činjenicom da ukoliko poduzeća ulažu sredstva u obnovu i povećanje svojih kapaciteta, posljedično utječu na povećanje novčanog toka od svoje primarne aktivnosti jer to je u konačnici i cilj poslovanja.

Iz svega navedenoga može se zaključiti da je u hotelskoj industriji broj godina otplate ukupnih obveza iz novčanog toka od poslovnih aktivnosti relativno nizak i kraći je od razdoblja amortizacije imovine zbog kojih su navedene obveze nastale. Razlog leži u činjenici da je hotelska industrija posljednjih godina sve 
profitabilnija zbog produženja turističke sezone, zaokreta prema bogatijim gostima koji su spremni dobru uslugu platiti više i slično.

Glavna ograničenja ovoga rada očituju se u tome što je analiza napravljena na temelju poduzeća čija je primarna djelatnost hotelijerstvo, a koja ostvaruju pozitivan novčani tok, dok su hoteli s negativnim novčanim tokom izuzeti iz analize, međutim to ograničenje najveći utjecaj ima samo na podatke u 2010. godini jer u ostalim godinama je broj poduzeća s negativnim novčanim tokom zanemariv.

U tablici 6. se nalazi analiza međuovisnosti koeficijenta zaduženosti i novčanog toka od poslovnih aktivnosti. Analiza je napravljena za 2014. i 2015. godinu, a prilikom izračuna iz analize su isključeni outlieri koji zbog velike raspršenosti podataka o novčanom toku od poslovnih aktivnosti utječu na rezultate korelacije. Prije računanja korelacije bilo je potrebno izračunati koeficijent zaduženosti kao omjer ukupnih obveza i ukupne imovine. Nakon izračuna koeficijenta zaduženosti za svako pojedino poduzeće u uzorku, napravljena je korelacija između koeficijenta zaduženosti i novčanog toka od poslovnih aktivnosti za svako razdoblje.

Tablica 6. Korelacija između koeficijenta zaduženosti i novčanog toka

\begin{tabular}{|c|c|c|}
\hline & $\mathbf{2 0 1 4 .}$ & $\mathbf{2 0 1 5 .}$ \\
\hline Koeficijent korelacije & $-0,18036529$ & 0,262372 \\
\hline Izvor: Obrada autora & & \\
\hline
\end{tabular}

Iz tablice 6. je vidljivo kako je u 2014. godini korelacija negativna međutim radi se o jako slaboj povezanosti, dok je u 2015. godini korelacija pozitivna ali slaba. Zbog slabe povezanosti nije moguće donijeti zaključak o međuovisnosti koeficijenta zaduženosti i novčanog toka od poslovnih aktivnosti. Stoga se kao ograničenje ovog rada može navesti kratko razdoblje analize podataka i problem velike raspršenosti podataka o novčanom toku od poslovnih aktivnosti koji utječe na koeficijent korelacije.

\section{ZAKLJUČAK}

U svakodnevnom poslovanju menadžeri donose brojne odluke pri čemu su vrlo značajne odluke o financiranju poduzeća. Svakom je poduzeću svojstveno da dio svoje imovine financira iz vlastitih izvora (kapitala), dok se drugi dio imovine financira iz tuđih izvora (dugovi). Dugovi se primarno podmiruju novcem. Novac se koristi i za nabavku nove opreme, izgradnju novih objekata, isplatu plaća i doprinosa, isplatu dividendi, plaćanje obveza po kreditima i izdanim dužničkim vrijednosnim papirima. Poslovanje koje generira dobit i pozitivne novčane tokove smatra se uspješnim poslovanjem. U ovom radu provedena je analiza i trendovi u kretanju novčanog toka iz poslovnih aktivnosti, a dobiveni rezultati ukazuju na 
značajan trend povećanja broja poduzeća koja ostvaruju pozitivan novčani tok od poslovnih aktivnosti u promatranom razdoblju (2010.-2015.). S obzirom da promatrano razdoblje obuhvaća razdoblje nakon globalne recesije, evidentan je trend oporavka i povećanja uspješnosti poslovanja poduzeća iz hotelske industrije u promatranom razdoblju. Analizom ukupnih obveza i trendova u njihovom kretanju utvrđeno je da je tijekom promatranog razdoblja došlo do povećanja ukupnih obveza što je posljedica novih investicija u hotelskoj industriji. Na temelju analize pokazatelja novčanog pokrića ukupnih obveza i broja godina potrebnih da se iz ostvarenog pozitivnog novčanog toka iz poslovnih aktivnosti pokriju sve obveze vidljivi su pozitivni trendovi, te se zaključuje da se tijekom promatranog razdoblja smanjuje broj razdoblja potreban za pokriće ukupnih obveza poduzeća. Finalno, rezultati provedenog istraživanja su pokazali da između koeficijenta zaduženosti i novčanog toka od poslovnih aktivnosti nije moguće donijeti validan zaključak o njihovoj međuovisnosti zbog vrlo slabe povezanosti između ovih varijabli. Kao ograničenje ovog istraživanja može se navesti kratko razdoblje koje je obuhvaćeno istraživanje, kao i usmjerenost samo na hotelsku djelatnost.

\section{LITERATURA}

1. Allen, D.E., (1993), The pecking order hypothesis: Australian evidence, Applied Financial Economics, Vol. 3, No. 2, str. 101-112.

2. Baskin, J., (1989), An empirical investigation of the pecking order hypothesis, Financial management, Vol. 18, No. 1, str. 26-35.

3. Bhandari, S.B., Iyer, R., (2013), Prediting business failure using cash flow statement based measures, Managerial Finance, vol. 39, No. 7, str. 667-676.

4. Fabozzi, F.J., Drake, P.P., (2010) The Basics of Finance, John Wiley \& Sons, Inc., Hoboken, New Jersey.

5. Fama, E.F., French, K.R., (2002), Testing trade-off and pecking order predictions about dividends and debt, Review of Financial Studies, Vol. 15, No. 1, str. 1-33.

6. Giacomino, D.E., Mielke, D.E., (1993), Cash flows: another approach to ratio analysis, journal of Accountancy, March, str. 55-58.

7. Gulin, D., (2016) Slobodni novčani tok - značaj i izračun prema MRS-u 7, Računovodstvo i financije, Vol. LXII, No. 4, str. 30-33.

8. Gulin, D., Hladika, M., (2017), Information capacity of cash flow statement - do we use it enough?, Proceedings from MultiScience - XXXI. microCAD International Multidisciplinary Scientific Conference, Miskolc, Hungary, str. $1-8$.

9. Gulin, D., Hladika, M., (2018), Izvještaj o novčanim tokovima za 2017. godinu, Računovodstvo i financije, Vol. LXIV, broj 1, str. 104-113.

10. Gulin, D., Perčević, H., (2013), Financijsko računovodstvo - izabrane teme, Hrvatska zajednica računovođa i financijskih djelatnika, Zagreb. 
11. Gurtani, M.M., Mehr, A.A., (2015), Assessment of the relation between systematic risk and debt to cash flow ratio, International Journal of Engineering Research and Management, Vol. 2, No. 4, str. 57-67.

12. Jooste, L., (2006), Cash flow ratios as a yardstick for evaluating financial performance in African businesses, Managerial Finance, Vol. 32, No. 7, str. 569-576.

13. Lee, T.A., (1982), Laker Airways - the cash flow truth, Accountancy, june, str. 115-116.

14. Matemilola, B.T., Bany-Ariffin, A.N., Nassir Annuar, Md., (2014), Debt and cash flow relationship in pecking order theory of corporate financing: dynamic panel evidence, The Empirical Economics Letters, Vol. 13, No. 6, str. 617-623.

15. Mills, J.R., Yamamura, J.H., (1998), The power of cash flow ratios, Journal of Accountancy, Vol. 186, No. 4, str. 53-60.

16. Mossman, C.E., Bell, G.G., Swartz, L.M., Turtle, H., (1998), An empirical comparison of bankruptcy models, Financial Review, Vol. 33, No. 2, str. $35-54$.

17. Rezaei, M., Jafari, S.M., (2015), Identifying the relationship between financial leverage and cash flows of the companies listed in Tehran Stock Exchange, Indian Journal of Science and Technology, Vol. 8, No. 27, str. 1-13.

18. Sen, M., Eda, O., (2008), Testing of pecking-order theory in Istanbul Stock Exchange Market, International Research Journal of Finance and Economics, Vol. 21, str. 1450-2887.

19. Tong, G., Green, C.J., (2005), Pecking order or trade-off hypothesis? Evidence on the capital structure of Chinese companies, Applied Economics, Vol. 37, No. 19, str. 2179-2189.

20. Zeller, T.L., Stanko, B.B., (1994), Operating cash flow ratios measure a retail firm's ,,ability to pay“, Journal of Applied Business research, Vol. 10, No. 4, str. 51-59. 


\title{
Mirjana Hladika, PhD
}

Faculty of Economics \& Business, University of Zagreb, Zagreb, Croatia mhladika@efzg.hr

Ivana Valenta, mag. oec.

Faculty of Economics \& Business, University of Zagreb, Zagreb, Croatia ivalenta@efzg.hr

Ivica Milčić, univ. spec. oec.

Croatian Association of Accountants and Financial Experts, Zagreb, Croatia imilcic@rif.hr

\section{ANALYSIS OF INTERDEPENDENCE BETWEEN THE CASH FLOW AND INDEBTEDNESS IN HOTEL INDUSTRY IN CROATIA}

Received: September 1, 2018

Accepted: November 30, 2018

Review

\begin{abstract}
Companies in the contemporary business environment are exposed to strong competition, they are constantly in a certain type of contest, so in order to survive they have to expand and improve their activities, services and products on which they generate growth and profitability. Growth needs to be financed, and the key question is how cash flows and debts affect each other. The business goal of all companies is to provide sufficient cash to settle the liabilities (debts) of the company to suppliers, employees, creditors and others, as well as for the new investments. If a company fails to meet its due obligations, it can face with liquidity and solvency problems. The company should not retain significant financial resources, but it should beam on profit-maximizing activities. Accordingly, companies should base their cash management policy on the fulfilment of its debts to the external sources of finance, while a certain amount of money should be invested in projects and activities that would generate future cash flows and improve the company's profitability. The aim of this paper is to analyze the interdependence between the cash flow from operating activities and the indebtedness of companies in the hotel industry, and to determine the financial coverage of total liabilities for companies from the hotel industry in Croatia.
\end{abstract}

Keywords: cash flow, indebtedness, hotel industry, Croatia;

JEL: M40, M41 